\title{
PIEZOELECTRIC MODEL FOR ACTIVE PROTON TRANSPORT IN BACTERIORHODOPSIN*
}

\author{
P.B. Kietis ${ }^{\mathrm{a}, \mathrm{b}}$, P. Saudargas ${ }^{\mathrm{a}}$, and L. Valkūnas ${ }^{\mathrm{a}, \mathrm{c}}$ \\ ${ }^{a}$ Institute of Physics, Savanoriu 231, LT-02300 Vilnius, Lithuania \\ E-mail: saudargas@ar.fi.lt \\ ${ }^{\mathrm{b}}$ Department of Radiophysics of Faculty of Physics, Vilnius University, Saulettekio 9, LT-10222 Vilnius, Lithuania \\ ${ }^{\mathrm{c}}$ Department of Theoretical Physics of Faculty of Physics, Vilnius University, Sauletekio 9, LT-10222 Vilnius, Lithuania
}

Received 9 June 2005

\begin{abstract}
Bacteriorhodopsin is a photoactive protein performing the transmembrane proton pumping through the purple membrane of Halobacterium salinarum. Experimental results of the electrical studies of the dried purple membrane films excited by short light pulses are presented. The time constant of the photoelectric response of the purple membrane film corresponds to the optically detectable L intermediate lifetime that is tens of micro seconds. Absence of the positive part of the photoelectric response signal in the time range of tens of microseconds under acidic conditions supports the assumption about the possibility of blockage of the proton transfer. The polarization field is a stimulating factor of the active proton transfer according to the assumption of the suggested two-state model. The mechanical-electrical properties of the dipole materials and the piezoelectric effect of the hydrogen bonds are discussed in the context of the zwitterionic state of the Schiff base and its counter ion Asp85. On the basis of the recent crystallographic data and molecular dynamics simulations it is concluded that the polarization of the Schiff base is a consequence of the mechanically strained hydrogen bonds caused by the retinal photoisomerization. The reorganized $\mathrm{H}$-bond network impedes the proton way back, and the proton accomplishes work while moving in the external circuit.
\end{abstract}

Keywords: bacteriorhodopsin, photoresponse, piezoelectric effect

PACS: $80,87.14,87.15 .-\mathrm{v}, 87.80$

\section{Introduction}

Bacteriorhodopsin (BR) is a simple transmembrane protein performing the active proton pumping through the purple membrane (PM) of Halobacterium salinarum $[1,2]$. Structurally, this protein folds into seven transmembrane helices; one of them contains the Lys216 residue at which the chromophore retinal binds via a protonated Schiff base [3-8].

Three decades of site directed mutagenesis, timeresolved spectroscopy, low-resolution projection, and 3D maps have revealed many details of the BR structure and its changes during the photo-cycle. The structural organization of BR with $1.55 \AA$ resolution [9$12]$, and the structural changes in intermediates of the photo-cycle [13-20] are well determined and thus the pathway of the proton translocation across the membrane is outlined [21-24]. In spite of the knowledge of the structural details of the $\mathrm{L}$ intermediate, its changes

\footnotetext{
* The report presented at the 36th Lithuanian National Physics Conference, 16-18 June 2005, Vilnius, Lithuania.
}

in the course of the subsequent transition are still under discussion [15]. The process of the proton pumping in BR is triggered by the light absorption, resulting in redistribution of charges along retinal [25] followed by the trans-cis isomerization immediately after its electronic excitation [26]. Molecular dynamics simulation of the processes of the BR photo-isomerization and the proton transfer clarifies the events that could not be resolved by the crystallographic studies [27-31].

Despite the knowledge of the details in structural organization and well-defined proton positioning during its translocation across the membrane, the origin of the proton driving force still remains unknown. The very initial step of the proton translocation from the Schiff base to Asp85 (the rise of the M intermediate) is the key switch of the unidirectional active proton transport $[32,33]$. Together with transient absorption measurements providing the spectral identification and transition rates between corresponding intermediates, the electrical studies are also carried out in order to detect 
the electrogenicity of these states in the course of the proton translocation [34].

Flash-induced biphasic electric signals from bacteriorhodopsin in the PM were observed already in the first investigations 30 years ago [35-37]. Electrical studies were performed on dried purple membrane samples [38-40], on BR proteoliposomes, on BR adsorbed to millipore filters [41], and on BR incorporated into planar lipid membranes [42-43]. In recent years, studies of the photocurrent in purple membranes have also been carried out [44-46]. The photoelectric response signal (PERS) of the oriented BR samples was investigated under various conditions [46-51]. The effect of the external electric field on the rate constants of the PERS was also assigned [48].

Proton pumping is dependent on the external conditions, such as $\mathrm{pH}$, humidity, and concentration of cations (see, for instance, [44, 52-56]). This is also confirmed by a rapid feedback of the protein to the external electric field applied to BR as is convincingly demonstrated by atomic force microscopy [21,57]. These studies have shown that the protein dynamics initiated by light causes the changes in the volume of the protein. Helix deformations are coupled to the active proton transfer $[16,58]$, hence the mechanical deformation of the BR molecule might be one of the key factors driving the unidirectional proton pumping.

Electrical studies of the dried films of the PMs also demonstrated the deformation of the BR molecule in the presence of the external electric field via the piezoelectric effect manifestation [34, 59]. It has been established that electrostriction is inherent in BR and, therefore, the piezoelectricity discovered in these systems is a result of the transmembrane electric field in the electrostrictive medium. It is noteworthy that electrostrictive properties were also identified for other ion channels [60].

Thermodynamic modelling of the processes usually follows the Gibbs energy minimization. In accord with this procedure, a variety of energy forms from the physical point of view can be used for characterization of a particular complex system. Because of that, transitions between various energy forms are expected in the thermodynamic system after its mechanical perturbation. Complicated molecular structures are capable of fulfilling such kind of transformation, especially concentrating the energy in chemical bonds. As a result, the external pressure applied to the piezoelectric medium permits uprising of the macroscopic electrical field. Such type of the energy conversion is well-characterized by the Le Chatelier's Principle (see, for instance, [61]).
Initial proposition of a physical model of the proton transfer in BR was already suggested two decades ago [62]. The presented model was supposed to be universal and adaptable to other membrane and enzymatic systems. The model of the energy conversion was also postulated on the basis of the piezoelectric effect identified in the BR films [63]. The electric field accompanied by the increase of the electric conductivity as a result of the piezoelectricity is responsible for the electrochemical potential to be generated. This can be considered as a reverse course of the energy transformation: the electric field of the membrane caused by the presence of ions and the increase of the electric conductivity result in accumulation of the mechanical energy terminating in a new chemical bond formation. Such type of studies was continued, however, the recent $\mathrm{X}$-ray diffraction data and molecular dynamics simulations provide the possibility to attribute the piezoelectricity to the H-bond network and to the electro-elastic properties of a hydrogen bond.

Herein we propose the modified version of the physical model of the proton transfer in BR [34] based on our new experimental results (see also [46, 51, 64] and the newest structural knowledge of the protein and its changes during the photocycle $[15,16,24]$. The height of an energy barrier between the Schiff base (SB) and Asp85 in BR decreases after photon absorption thus initiating the first step in proton pumping. The experimental results demonstrate that this step of proton transfer might be blocked in the dried films by acidification, however, the initial stage of the photo-response signal remaining unchanged (see also [56]). The alternating height of an energy barrier could be considered as an analogue of a valve in the mechanical pump for the electrical particles in the ion pumping. A proton is driven because of the presence of the electric field from the proton donor - the SB - to the acceptor - Asp85. Experimental results presented here enable us to conclude that the first (fast negative) part of the photoelectric response is of the polarization origin. This electric polarization causing the proton transfer is the main feature of our model.

\section{Materials and methods}

\subsection{Sample preparation}

Oriented PM films of Halobacterium salinarum were electrophoretically precipitated on a glass plate coated with the ITO (indium-tin-oxide) layer according to the standard procedure $[39,47]$. The area of the 
film surface was $0.5 \mathrm{~cm}^{2}$ in size. The ITO layer served as a light-transparent electrode for measuring the optical density and the photoelectric potential of the film. The load resistance of the potential measuring equipment was chosen to be $10^{12} \Omega$. The optical density of the film was $\approx 2$ optical units and the thickness was $\approx 14 \mu \mathrm{m}$.

External $\mathrm{pH}$ conditions were varied by treating films with acid for various periods of time. The sample was soaked for 1 minute in $0.1 \mathrm{M} \mathrm{HCl}$ solution (reaching the so-called low $\mathrm{pH}$ conditions) or for 2 minutes in $1 \mathrm{M} \mathrm{HCl}$ solution (reaching very low $\mathrm{pH}$ conditions) and afterwards dried in the air. It is noteworthy that the acidification effect is reversible.

Temperature dependences of the time constant of the photoresponse in the temperature range from 0 to $50^{\circ} \mathrm{C}$ were measured using a home built thermostat. Temperature was changed by a gas flow of appropriate temperature.

\subsection{Photoresponse}

Second harmonics $(532 \mathrm{~nm})$ of the Q-switched Nd:YAG laser was used for the optical excitation of the sample. The energy of the excitation light pulse was $\approx 10 \mathrm{~mJ}$, pulse duration $\approx 3 \mathrm{~ns}$. A home built set-up, schematically shown in Fig. 1, was used to measure the PERS. The voltage generated by light depends on the orientation of the film. The PERS experimental results were obtained by averaging 50 separate photoresponses. A detailed description of the PERS measurement is presented elsewhere [34, 46, 59].

\section{Results and discussion}

\subsection{Experimentally detected $\mathrm{pH}$ effect}

Typical kinetics of the photoelectric response of the oriented PM film are presented in Fig. 2 (solid line). The photo-response is characterized by two phases, a negative signal $(\approx 2 \mu \mathrm{s})$ is followed by a positive one $(\approx 40 \mu \mathrm{s})$, which can be attributed to the proton pumping ( $\mathrm{L}$ to $\mathrm{M}$ transition in the BR photocycle). The photo-electric response of the oriented PM film under high acidification conditions contains only the first component (fast, negative) (see Fig. 2, dotted line). The intermediate curve (dashed line) represents the PERS of the PM film when the membranes are only partly influenced by the density of the protons under low $\mathrm{pH}$ conditions.

By comparing acidification results with temperature studies (see bellow) it is evident that the value of the

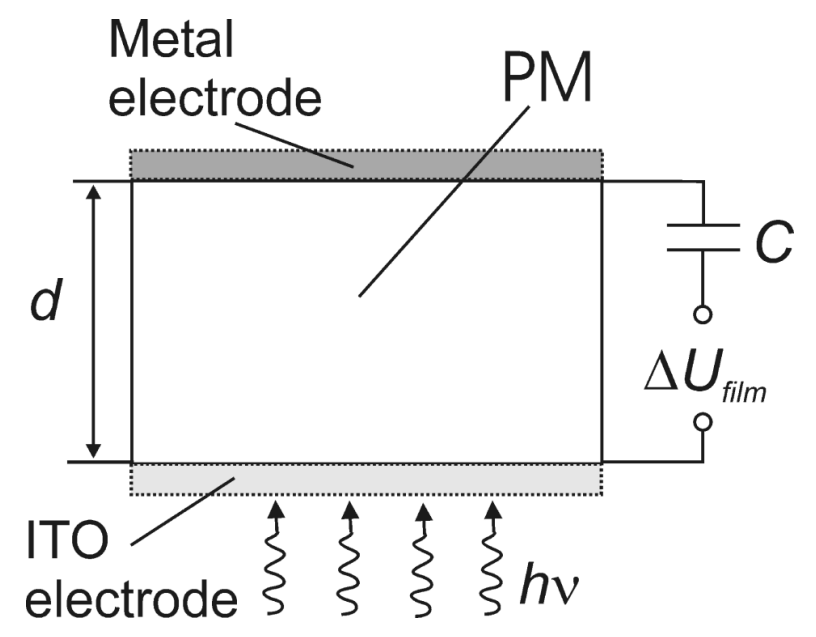

Fig. 1. Experimental scheme describing the PERS studies. The dried PM film serves as a dielectric medium between two electrodes, the metal (above) and the light transparent ITO conducting glass (below). The total thickness of the PM film is indicated as $d, R$ is an external resistor, which was chosen to be $1.5 \cdot 10^{9} \Omega$, and $U_{0}$ determines the bias electric potential that is applied to the sample by means of the electrical switch $P . \Delta U_{\text {film }}$ indicates the electric potential generated by light in the film, while the external capacitor $C$ of $100 \mathrm{pF}$ cuts off the constant bias potential.

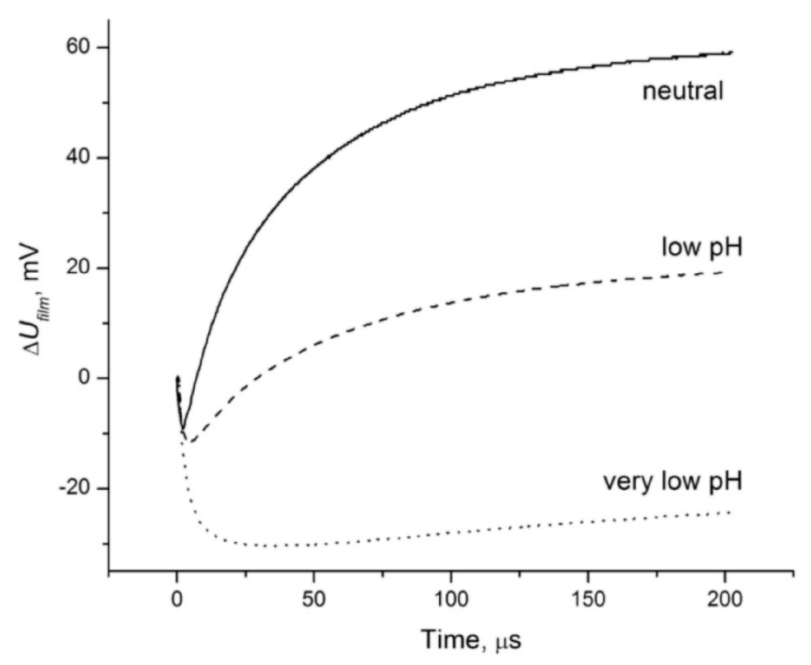

Fig. 2. Experimental results of the photoresponse $\Delta U_{\text {film }}$ after light excitation of the oriented dried PM film at different $\mathrm{pH}$ : neutral (solid line), low $\mathrm{pH}$ (dashed line), and very low $\mathrm{pH}$ (dotted line). The amplitude of the positive part of the PERS signal is lowered while lowering $\mathrm{pH}$.

PERS amplitude decreases with increasing the level of the acid treatment, while the time constant remains unchanged. Qualitatively this can be understood assuming that the characteristic time of the PERS decay remains the same in the active pathways, while the number of the active pathways of the proton transfer decreases because of the acid treatment. 


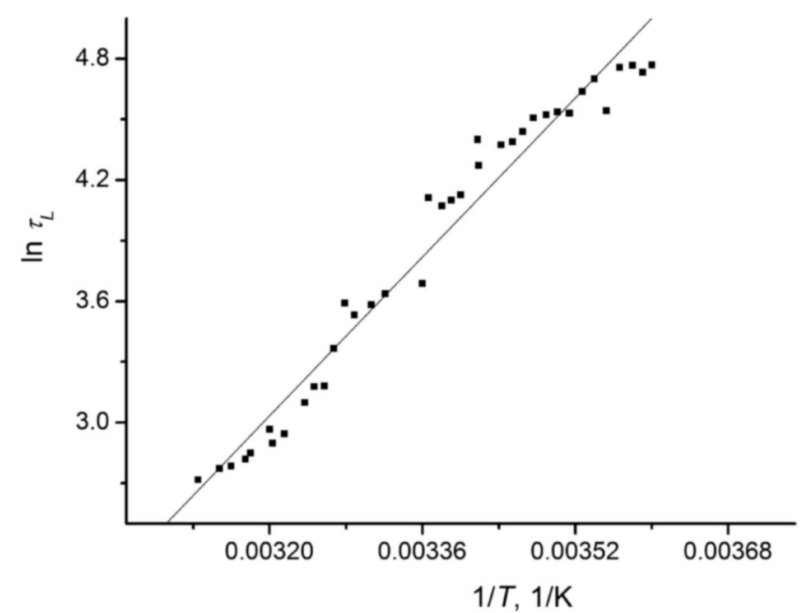

Fig. 3. Temperature dependence of the time constant of the positive part of PERS of the PM film plotted in Arrhenius coordinates.

\subsection{Temperature effect}

The PERS kinetics of the non-oriented film are temperature-dependent as demonstrated in Fig. 3. For lower temperatures the response amplitude of the positive part decreases and the time constant $\tau_{L}$ increases. Temperature dependence of the time constant of the positive part of the PERS is linear in the Arrhenius coordinates in the temperature range from 0 to $50^{\circ}$ $\mathrm{C}$ (Fig. 3) with the activation energy of this process $W_{\mathrm{L}} \approx 0.46 \mathrm{eV}$.

\subsection{Two-state model of the proton transfer}

The Grotthuss model describes the proton movement along a particular one-dimensional pathway. The same concept is used to describe the ion movement in biological channels and in carbon nanotubes [65]. To describe the blockage possibility of a particular step of the proton transfer the occupation factor $\vartheta$ should be introduced. The occupation factor $\vartheta=0$ if the site is vacant and $\vartheta=1$ if the site is occupied. Hereinafter we use the occupation factor in constructing the two-state model.

The energy surface for the hydrogen bond between the SB and Asp85 is presented schematically in Fig. 4. The potential energy barrier (dotted line) in the ground state is too high for the proton to overpass it. Upon light excitation the barrier decreases by the $W_{\mathrm{P}}$ value (solid line) as a result of a piezoelectric feature of the medium $[34,51]$ and of the appearance of the corresponding polarization electric field $\vec{E}_{\mathrm{P}}$ in the active centre. The detailed explanation about the origin of the polarization electric field $\vec{E}_{\mathrm{P}}$ is presented in Appendix. Thus the appropriate conditions for the activation type proton transfer are established in the $\mathrm{L}$ intermediate with

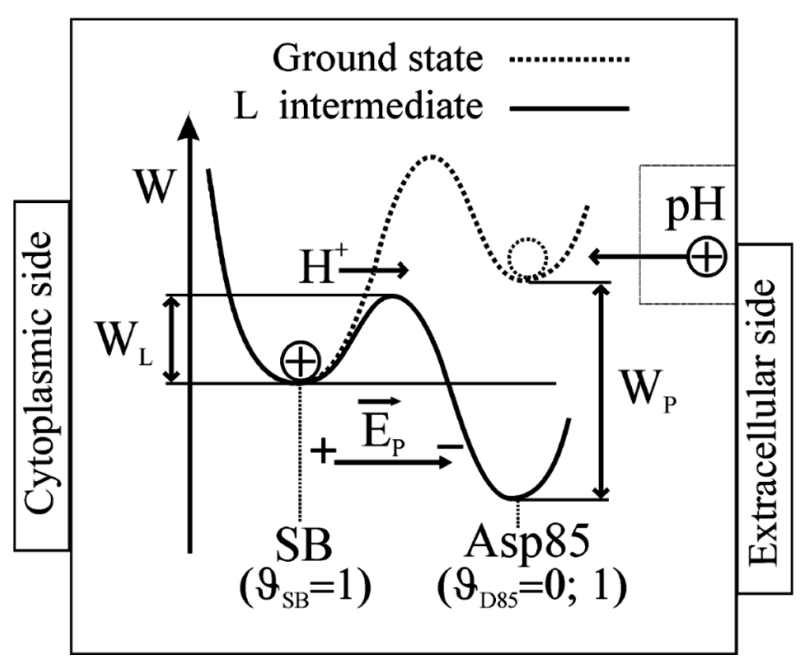

Fig. 4. Potential energy surfaces for the proton positioned between the SB nitrogen atom and the counter ion of the acceptor Asp85 in the ground state and in the $\mathrm{L}$ intermediate. SB is protonated (the occupation factor $\vartheta_{\mathrm{SB}}=1$ ) while the Asp85 is not protonated (the occupation factor $\vartheta_{\mathrm{D} 85}=0$ ) in the ground state (dotted line) and the probability for the proton $\mathrm{H}^{+}$to overcome the energy barrier is very small. The piezoelectric polarization field $\vec{E}_{\mathrm{P}}$ is the outcome of the light energy conversion in the active centre of BR during the light induced photo-cycle. The electric field of polarization $\vec{E}_{\mathrm{P}}$ diminishes the height of the energy barrier, creating the conditions suitable for the proton transfer in the $\mathrm{L}$ intermediate (solid line). Energy of the decreased barrier is $W_{\mathrm{L}}$. The energy difference for protons at Asp85 in the potential well between the ground and excited state is defined as $W_{\mathrm{P}}$. The acceptor Asp85 could be protonated (the occupation factor $\vartheta_{\mathrm{D} 85}=1$ ) by the environment under low $\mathrm{pH}$ conditions, hence proton transfer from the SB is blocked.

a characteristic barrier height $W_{\mathrm{L}}$. However, in addition to the activation energy as the main characteristics of the proton transfer rate, the occupation factors of the initial and final states also play an important role. Evidently, under low $\mathrm{pH}$ conditions the acceptor Asp85 can be protonated $[6,56,66,67]$ and the occupation factor of this state by the proton reaches unity, i. e. $\vartheta_{\mathrm{D} 85}=1$, therefore the proton transfer is blocked according to this model.

When the proton transfer $\mathrm{SB} \rightarrow \mathrm{Asp} 85$ is fulfilled, the electric field $\vec{E}_{\mathrm{P}}$ of polarization vanishes due to release of the mechanical strains (see Appendix for details), while the electric field $\vec{E}_{\mathrm{H}}$ of the opposite direction created by the energized proton persists (see Fig. 5).

Initially the active centre of BR is in the zwitterionic state where the positively charged nitrogen atom of the protonated Schiff base is connected to its counter ion oxygen of Asp85 - via the water molecule. During the photocycle this water molecule is released from its original position simultaneously with an arrangement of a new hydrogen bond, thus constructing a pathway for the proton transfer $[15,16,19,24]$. The simplified 


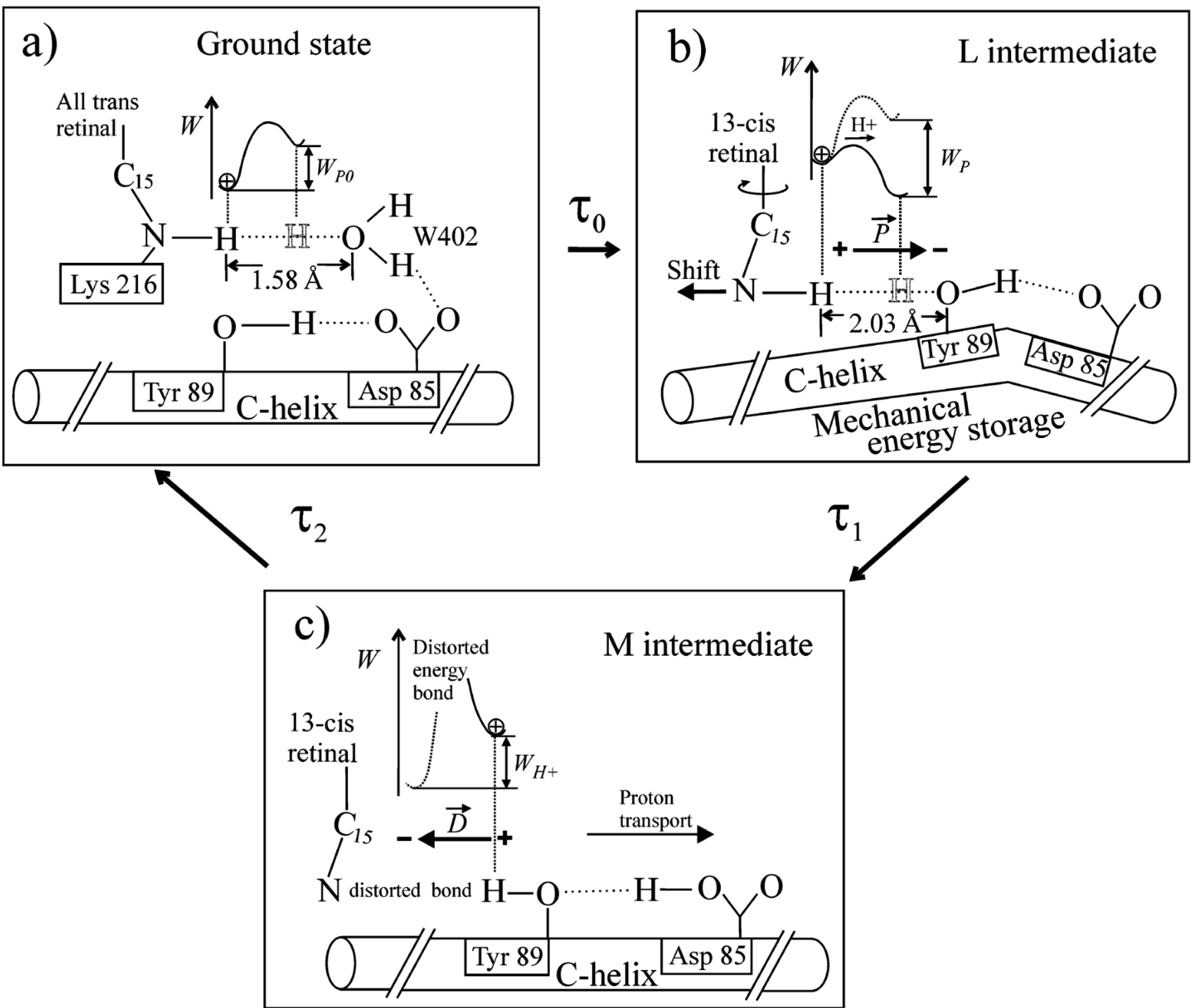

Fig. 5. The model of the presumptive deformations of the residues in the active centre of BR and corresponding potential energy surfaces of the proton in three stages of the active proton pumping: ground state, L state, and M state. (a) Ground state. Schiff base is protonated. The bond length between $\mathrm{H}$ and $\mathrm{O}$ atoms is $1.58 \AA$. $W_{P 0}$ is the energy gap between the possible proton positions: by the $\mathrm{N}$ atom of SB and the $\mathrm{O}$ atom of the water molecule W402. (b) L state. Conditions suitable for the proton transfer from SB to the acceptor are achieved in the $\mathrm{L}$ intermediate. Retinal is already isomerized to 13-cis conformation. Tyr89 changes the water molecule W402 and the new H-bond is established. $2.03 \AA$ is the length of the strained hydrogen bond. C-helix bends and the whole state is mechanically strained. The piezoelectric polarization $\vec{P}$ takes place and subsequently decreases the energy barrier for the proton to overcome. The energy of this electric polarization field is $W_{\mathrm{P}}$. (c) M state. The proton is already transferred to the acceptor Asp85. The donor-acceptor bond is distorted and the proton flow back is prohibited by a high energy barrier. The mechanical strains are relieved eliminating the piezoelectric polarization $\vec{P}$, however the opposite electric field of the proton $\vec{D}$ appears.

version of such kind of reorganization of the chemical bonds and the corresponding potential energy dependence on the proton positioning in regard to the $\mathrm{N}$ and $\mathrm{O}$ atoms is shown in Fig. 5. The energy surface and the potential minima follow from the molecular dynamics simulations [27]. According to these model simulations the oxygen atom is related to some generalized proton acceptor, while the lowest energy minimum corresponds to the proton positioned in the vicinity of the nitrogen atom resulting in protonation of SB in its ground state. The $\mathrm{L}$ intermediate is related with mechanical deformation of the $\mathrm{N}-\mathrm{H}$... O bond as a result of the piezoelectric polarization $\mathrm{P}$ (see Appendix). Thus, the shape of the energy potential in the L intermediate is the consequence of the superposition of the SB ground state potential and the polarization energy. The direction of the piezoelectric polarization should result in an increase of the probability of the proton transfer from SB towards the accepting oxygen atom. Thus, the proton pumping is driven by the piezoelectric polariza- 
tion and the corresponding driving force is well defined by a single parameter - the energy barrier $W_{\mathrm{L}}$.

\subsection{Photoresponse}

The experimentally observed transient signals reflecting the $\mathrm{L}$ intermediate should be proportional to the total number of the BR molecules in this state. Temporal evolution of the $\mathrm{L}$ intermediate formation and decay satisfy the linear kinetic equations describing this model (see for details [34]). The evolution of electrically distinguishable intermediates follow: $\mathrm{BR} \stackrel{\tau_{0}}{\longrightarrow} \mathrm{L} \stackrel{\tau_{\mathrm{L}}}{\longrightarrow} \mathrm{M}$. The kinetics of the photoresponse $\Delta U_{\text {film }}^{\mathrm{N}}$ which is proportional to the sum of BR concentrations in the intermediates $\mathrm{L}$ and $\mathrm{M}$ could be expressed theoretically:

$$
\begin{aligned}
\Delta U_{\text {film }}^{\mathrm{N}}= & k \cdot B R^{*}\left[1-2 \frac{\tau_{\mathrm{L}}}{\tau_{\mathrm{L}}-\tau_{0}} \cdot \exp \left(-\frac{t}{\tau_{\mathrm{L}}}\right)\right. \\
& \left.+\frac{\tau_{0}+\tau_{\mathrm{L}}}{\tau_{0}-\tau_{\mathrm{L}}} \cdot \exp \left(-\frac{t}{\tau_{\mathrm{L}}}\right)\right],
\end{aligned}
$$

where $k$ is the coefficient to match dimensions, $B R^{*}$ is the amount of the excited BR molecules (under normal $\mathrm{pH}$ conditions), while

$$
\tau_{\mathrm{L}}=\frac{1}{\nu_{0} \vartheta_{\mathrm{SB}}\left(1-\vartheta_{\mathrm{D} 85}\right)} \cdot \exp \left(\frac{W_{\mathrm{L}}}{k T}\right)
$$

is the time constant of the lifetime of the $\mathrm{L}$ intermediate, $\nu_{0}$ is the proton oscillation frequency in the initial state. The occupation factor of the SB $\vartheta_{\mathrm{SB}}=1$ and that of the acceptor Asp85 $\vartheta_{\mathrm{D} 85}=0$ correspond to the normal conditions when the proton is positioned in the initial state. At low $\mathrm{pH}$ of the environment the proton acceptor Asp85 is protonated, thus $\vartheta_{\mathrm{D} 85}=1$ (see [56]). Hence from Eq. (2) we get that $\tau_{\mathrm{L}}=\infty$, and the resultant PERS of such BR molecules equals to

$$
\Delta U_{\text {film }}^{\mathrm{A}}=-k \cdot B R_{\mathrm{A}}^{*}\left[1-\exp \left(-\frac{t}{\tau_{0}}\right)\right],
$$

where $\Delta U_{\text {film }}^{\mathrm{A}}$ represents the response of the film at very low $\mathrm{pH}$ and $B R_{\mathrm{A}}^{*}$ is the amount of the excited BR molecules under the acidic conditions. Theoretical curves (see Fig. 6) were calculated using Eqs. (1) and (3) with the corresponding coefficients well correlating with the experimental data obtained for the oriented PM films under neutral and acidic conditions (see Fig. 2). Slight deviation of the calculated results from the experimental photoresponse is due to simplification of the model and neglection of the heterogeneity of the $\mathrm{M}$ intermediate.

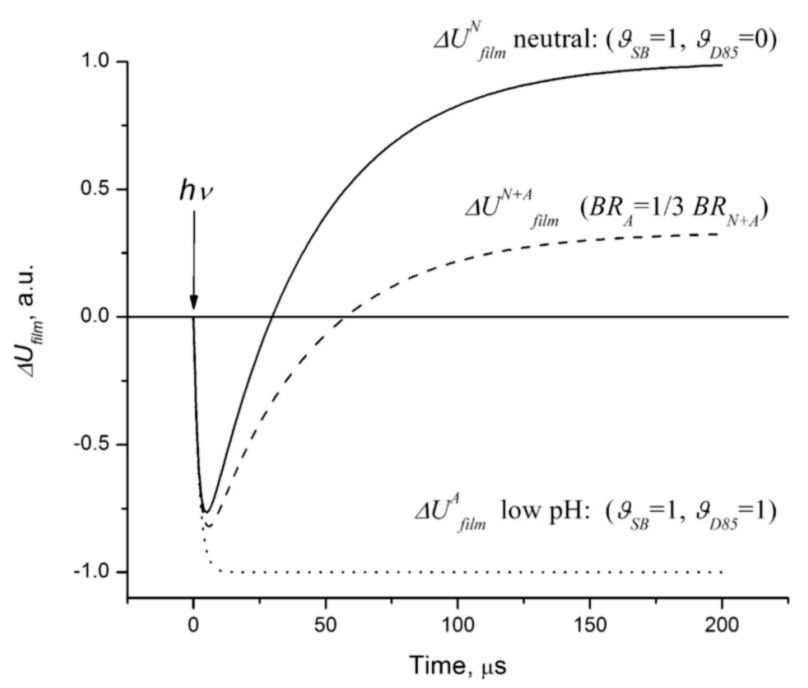

Fig. 6. Theoretical curves of the PERS time dependence in the oriented PM film during the active proton transfer in the L to M transition. The PERS of the film under neutral conditions $\Delta U_{\text {film }}^{\mathrm{N}}$ (upper solid line) is calculated from Eq. (1) with the time constant of $40 \mu \mathrm{s}$. The PERS of the film in the low $\mathrm{pH}$ environment, $\Delta U_{\text {film }}^{\mathrm{A}}$, (lowest dotted line) is calculated in accord with Eq. (3) (the occupational factors of SB and Asp85 are indicated). The resultant potential of the sum of the normal and acidic fractions is calculated using the superposition of Eqs. (1) and (3), taking in account that the acidic fraction $B R_{\mathrm{A}}=1 / 3 B R$ (the middle dashed line).

We propose a very simple method to measure $\tau_{\mathrm{L}}$, which represents the lifetime of the L intermediate under different conditions. Although the L structure is known from the crystallographic data $[14,16,68]$ the exact structural organization is still under debate [15]. Hence there is no unified view of the first proton transfer step from the Schiff base to the acceptor Asp85, i. e., either the proton is transferred directly to Asp85 or via the Thr89. Conceptually the presented two-state model assuming the deformation of the H-bond network as a main feature is independent of this problem.

\section{General}

The electrochemical membrane potential is the final product of the energy conversion induced by the light absorption in the BR molecules. Energy accumulated during the initial step, which is the retinal photoizomerization, is later converted into the mechanical energy form [17]. The two-state model was developed to explain the experimental observations.

Summarizing our results we declare that after excitation of the BR molecule by the light pulse the electrically distinguishable intermediate appears synchronically with the optically distinguishable L intermediate. The electric field of the polarization origin that induces the proton flux is the characteristic feature of 
this intermediate. The polarization field is an outcome of the piezoelectric effect of the H-bond between SB and counter ion Asp85. Our previous experimental observations revealing that in the ground state the PM film exposes the polarization electric field directed towards the extra-cellular side confirm this conclusion [34]. Manifestation of direct and inverse piezoelectric effects [63] as well as electrostrictive properties of BR $[34,46,51,59]$ are also in line with those conclusions. The presented mechanism of the active proton pumping in BR is reasoned by our experimental observations of photo-response and electro-acoustic studies, the piezoelectric concept, recent molecular dynamics simulations [27-31], and X-ray crystallographic data [9-12]. The H-bond network including the intramolecular $\mathrm{H}_{2} \mathrm{O}$ molecules protects the protein environment from the destruction as a damper suppressing a sudden mechanical strain upon retinal photoisomerization.

Contrary to the aqueous BR samples the dried films do not contain the electrically conducting aqueous layer, which has strong influence on the capacitance of the membrane. This electric capacitance of the membrane is obviously the main bioenergetic element of the cell. In our scheme the energized protons in the active centre do not "have" to charge a big membrane capacitance in the dried films because of its absence. Hence, the electrical measurements in the dried PM films reflect only the characteristic electric events in the active centre of the BR molecule. Lack of water in the system does not restrict the light energy conversion. The electric processes are shielded (integrated) by a big capacitance in aqueous conditions, therefore, becoming unrecognizable. This could be the reason for differences in the results obtained by other photo-electric measurements $[39,69]$. Different interpretations of the primary photo-electric signals confuse the general concept of the electrogenic energy conversion.

The inverse piezoelectric effect should also take place according to our model based on the direct piezoelectric effect, since the deformation is originated from the flux density of the energized protons. The bending of the F-helix in the M intermediate [20] could be understood invoking this concept presented above. The time constant of this intermediate is relatively very long in the dried PM films, of the order of the value greater than in the aqueous solution because the energized proton does not move in the exterior circuit [70]. In this case the proton back transfer to SB via the intramolecular bonds defines the energy relaxation, therefore, it takes more time than in aqueous conditions.
While the electric field of the proton disappears during the following transport cycle step, the consequent mechanical deformation of the F-helix of the protein also vanishes. Thus, we come to the final conclusion that the energy of the deformed active centre is utilized for the synthesis of the $\mathrm{N}-\mathrm{H}$ chemical bond.

\section{Acknowledgement}

Authors are grateful to the Lithuanian State Science and Studies Foundation (agreement No. T-04185) for the financial support of the project.

\section{Appendix}

\subsection{Piezoelectric effect in polar solids and polymers}

Chemical bonds could be characterized by the electrostatic and elastic energies because of interaction between atoms. Piezoelectric materials are known as mechano-electric energy converters due to these characteristics. A typical model of one-dimensional periodic electro-elastic chain is depicted in Fig. 7. Dipoles $p_{1}=-q(a-b)$ and $p_{2}=-q b$ of opposite direction create the single unit of this chain. Here $q$ is a unitary charge, $b$ is the distance between opposite charges, and $a$ is the length of the unitary cell of the lattice. The resultant dipole momentum $p_{0}=q(2 b-a)$. The electric polarization describes the dipole moment of a single unit, thus

$$
P_{0}=n q(2 b-a),
$$

where $n$ is the volume concentration of the dipoles. The length of the springs and the dipole moments $p_{1}$ and $p_{2}$ vary when deforming the chain by the external force $F_{e x}$. Consequently, the electric polarization also changes, resulting in

$$
P=\Delta P_{0}=n q(2 \Delta b-\Delta a) .
$$

Designating the deformation as $S=\Delta a / a$, and following the electromechanical model shown in Fig. 7 from Eq. (5) it follows that

$$
P=\beta \cdot S,
$$

where $\beta$ is the piezoelectric module of the material,

$$
\beta=n a q \frac{k_{1}-k_{2}}{k_{1}+k_{2}},
$$

$k_{1}$ and $k_{2}$ are the elasticities of both springs, respectively. 


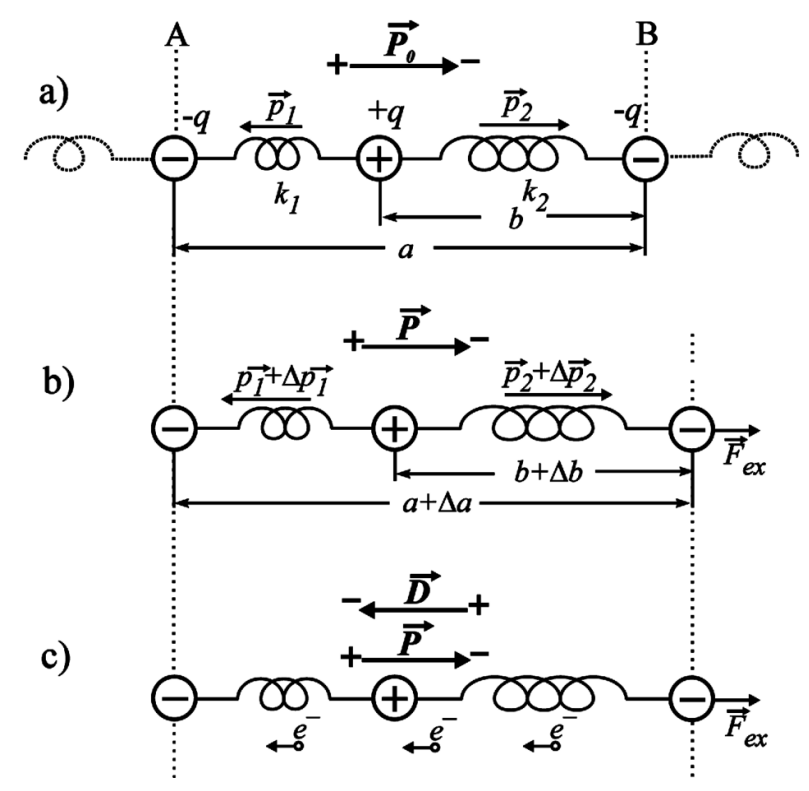

Fig. 7. Physical model of the piezoelectric effect in polar solid or polymer material. A one-dimensional chain of ions periodically distributed in the material is shown. $A, B$ are the surfaces of the elementary grating; $-q,+q$ are the charges of ions; $b$ is the distance between charges of the single dipole; $a$ is the total length of two dipoles; $k_{1}, k_{2}$ are mechanical resiliences of dipoles determined by the quantum mechanical attractions; $\vec{p}_{1}, \vec{p}_{2}$ are the dipole momenta of the chemical bonds. (a) $\vec{P}_{0}$ is the electric polarization and its direction in the given coordinate system of the material in equilibrium when $b>(a-b)$. (b) Changes of the distances between atoms $\Delta a, \Delta b$ and the dipole moments $\Delta p_{1}$ and $\Delta p_{2}$ upon the density of the external force $F_{\text {ex }} . \vec{P}$ is the resultant dipole moment of the single volume (electric polarization) in the case when $k_{1}>k_{2}$. (c) The electric flux density $\vec{D}$ is originated due to the free charges $e^{-}$(electrons or ions) movement in the polarization field $\vec{P}$. This results in the compensative effect of both these fields,

$$
\text { i. e., } \vec{P}+\vec{D}=0 \text {. }
$$

The direct piezoelectric effect is expressed by Eq. (6), which is evidently absent if the elastic constants of both springs are equal, i. e., $k_{1}=k_{2}$, as follows from Eq. (7).

Free charges move in the polarization field and accumulate in the surface in the conductive system. The surface density of these charges defines the electric flux density $\vec{D}$, which shields the polarization field in equilibrium, i. e., $\vec{P}+\vec{D}=0$. By taking into account Eq. (6) we will get more elaborate expressions:

$$
\begin{gathered}
T=c S-\beta E, \\
D=E \varepsilon \varepsilon_{0}+\beta S,
\end{gathered}
$$

where $T$ is the density of external force $F_{\text {ex }}$ to the crystal surface, $E$ is the total electric field combined by the polarization and the electric flux, $\varepsilon_{0}$ and $\varepsilon$ are electric and dielectric constants, respectively. The elastic module of the medium $c$ is expressed through the elements of the elastic constants $k_{1}$ and $k_{2}$ of a single chain as follows:

$$
c=n a^{2} \frac{k_{1} k_{2}}{k_{1}+k_{2}} .
$$

In the case of non-conducting piezoelectric medium $D=0$, and then from Eqs. (8) and (9) we will get:

$$
T=c\left(1+\frac{\beta^{2}}{c \varepsilon \varepsilon_{0}}\right) S .
$$

The energy of deformation is defined as $W_{s}=$ $1 / 2 c S^{2}$, and the energy of the electric field can be given by $W_{E}=1 / 2 \varepsilon \varepsilon_{0} E^{2}$. Hence from Eq. (9), when $D=0$,

$$
\chi^{2}=\frac{W_{E}}{W_{S}}=\frac{\beta^{2}}{c \varepsilon \varepsilon_{0}},
$$

where $\chi^{2}$ defines the coefficient of the electromechanical coupling. This coefficient characterizes the efficiency of the conversion of the mechanical energy to the electrostatic energy form. This coefficient for the quartz crystal equals to $\chi^{2} \approx 0.01$. This crystal widely used in electro-technical applications converts only $1 \%$ of the mechanical energy to the electrostatic form. For the cesium dihydro phosphate $\left(\mathrm{CsH}_{2} \mathrm{PO}_{4}\right)$, the so-called CDP crystal, this coefficient equals to $\chi^{2} \approx 0.6$. High efficiency of the energy conversion in this crystal is determined by the $\mathrm{O}-\mathrm{H}$. . O hydrogen bonds, which are of the hydrogen bonding origin.

As follows from Eqs. (11) and (12), the effective elastic module of a piezoelectric environment is

$$
c_{\text {insul }}=c\left(1+\chi^{2}\right) \text {. }
$$

As it was already outlined, in the conducting piezoelectric medium $P+D=0$ and, thus, the resultant electric field $E=0$. Hence from Eq. (8) it follows that in the case of the conducting piezoelectric medium the elastic module

$$
c_{\text {cond }}=c \text {. }
$$

Thus, the elasticity of the piezoelectric medium depends on the electric conductivity. Hence the change in conductivity changes the mechanical elasticity of the material.

The dipole system is deformed under the external electric field if $k_{1} \neq k_{2}$ (see Fig. 7). The energy of the electric field is converted into the mechanical energy form. The deformation could be calculated using Eq. (8) when the density of the external force $T=0$. Then we will obtain that

$$
S=\frac{\beta}{c} E .
$$


a)

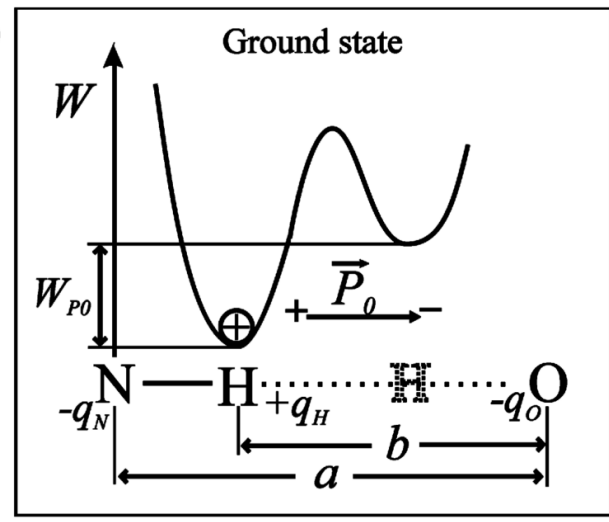

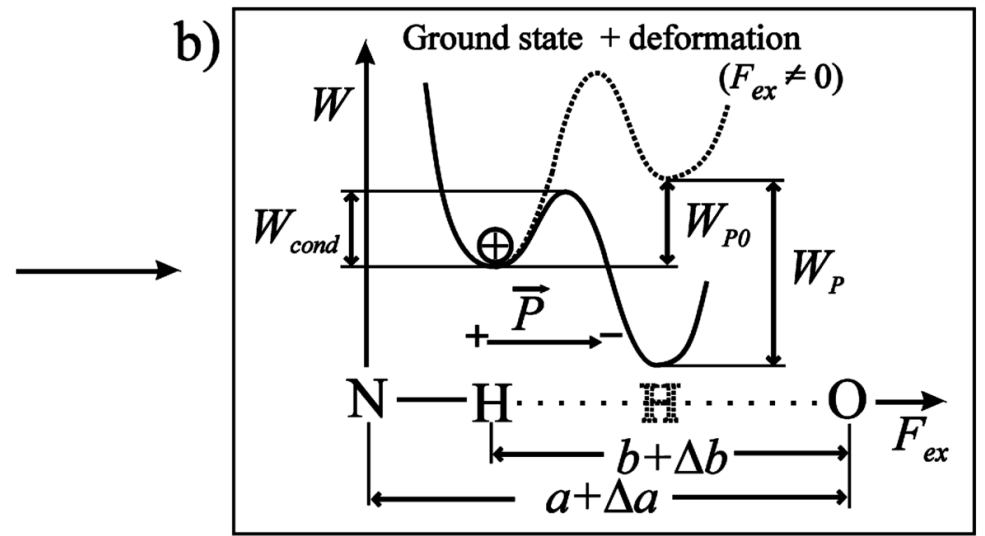

c)

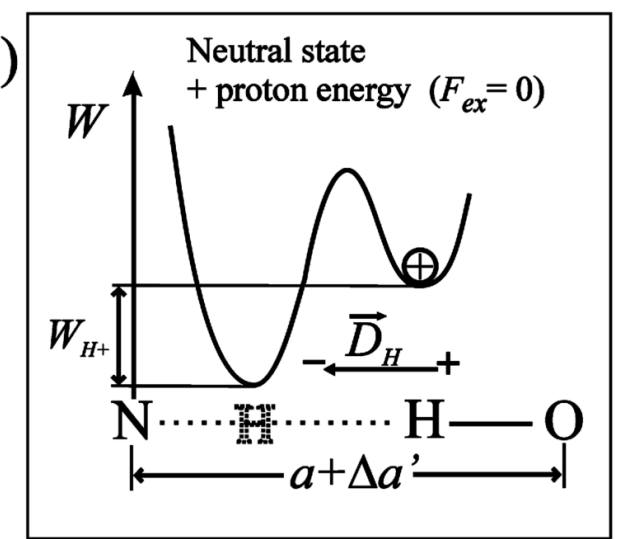

d)

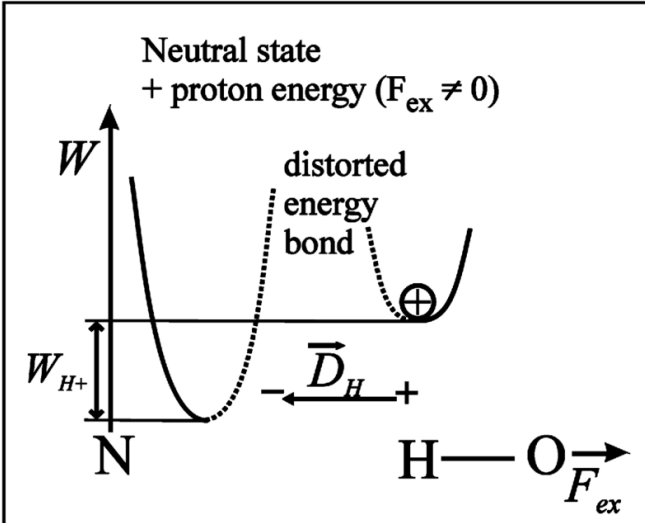

Fig. 8. Energy surface of a hydrogen bond and its evolution in the presence of the external force. N, H, O are the nitrogen, hydrogen, and oxygen atoms and their positions. $-q_{\mathrm{N}},+q_{\mathrm{H}},-q_{\mathrm{O}}$ are the charges of these atoms, respectively. (a) Free energy $W$ along two bonds: covalent $\mathrm{N}-\mathrm{H}$ and hydrogen $\mathrm{H} \cdots \mathrm{O}$ of the protonated SB with two potential minima; $a-b$ and $b$ are the lengths of these bonds, respectively. $\vec{P}_{0}$ is the initial electric polarization created by both chemical bonds in the ground state. (b) Dotted line curve corresponds to the ground state. Changes by the value $\Delta b$ indicate the change of the length of the hydrogen bond because of the presence of the external force $F_{\text {ex }}$. The proton overpasses the barrier $W_{\text {cond }}$ affected by the electric field of increased polarization $\vec{P}$. (c) After removing the external impact $F_{\text {ex }}$ the electric polarization $\vec{P}$ vanishes and the electric field of the opposite direction created by the electric flux density $\vec{D}_{\mathrm{H}+}$ remains. $W_{\mathrm{H}+}$ is the potential energy of the proton. (d) The hydrogen bond could be broken by the residual external force $F_{\text {ex }}$. The electric field of the energized proton remains $\left(\vec{D}_{\mathrm{H}+}\right)$.

The inverse piezoelectric effect manifests when the energy of the electric field is converted into the mechanical energy form.

\subsection{Piezoelectric properties of a hydrogen bond and the proton transfer in $B R$}

High efficiency of the mechano-electric energy in the CDP crystals could be accounted for the hydrogen bonds. The Schiff base, $\mathrm{N}-\mathrm{H} \cdots \mathrm{O}$, is asymmetric and also has a hydrogen bond with the first acceptor (in the L intermediate). Such SB state and the proton transfer were widely analyzed recently $[71,72]$. The active proton transfer occurs as a result of a steric repulsion of the intra-molecular hydrogen bonds in the Schiff base region. Here we discuss the properties of such hydrogen bond upon the impact of the external force referring to the model defined above.

The energy surfaces of the SB bond and its evolution under the influence action of the external force are depicted in Fig. 8. The length of the $\mathrm{N}-\mathrm{H}$ covalent bond $(a-b) \approx 1 \AA$ and the hydrogen bond $\mathrm{H}$... O length $b \approx 1.5 \AA$ in the ground state (Fig. 8(a)). The protonated Schiff base indicates that the energy minimum of the $\mathrm{H}$ atom is closer to nitrogen atom of SB. The two energy minima in the potential surface indicate the possibility for the proton to arrange a covalent bond with the oxygen atom thus resulting in deprotonation of SB. The probability of this action depends on the energy difference between two possible proton states $W_{\mathrm{P} 0}$. The energy surface and the atom positions of the deformed SB are presented in Fig. 8(b). The en- 
ergy and the elasticity of the hydrogen bond are much smaller than those of a covalent bond. The length of the $\mathrm{N}-\mathrm{H}$. $\mathrm{O}$ bond changes basically on account of the hydrogen bond, thus, $\Delta b \approx \Delta a$. Upon the external force action the situation when $k_{1} \gg k_{2}$ is satisfied and thus as defined by Eqs. (7) and (10)

$$
c_{\mathrm{H}}=n a^{2} k_{2}, \quad \beta_{\mathrm{H}}=n a q .
$$

The elastic module $c_{\mathrm{H}}$ and the piezoelectric module have the minimal values, while $\beta_{\mathrm{H}}$ has the maximal value in the H-bond network system. From Eq. (13) one can see that the coefficient of the electromechanical coupling gains the maximal value and the energy conversion is accomplished with the maximal efficiency in such oriented H-bond materials.

The proton energy of the distorted bond is illustrated in Fig. 8(b). This state originates from the ground state by the presence of the piezoelectric potential. The energy of this potential $W_{\mathrm{P}}$ could be found from changes of the length of the dipole $\mathrm{H} \cdots \mathrm{O}$ according to the Coulomb interaction

$$
W_{\mathrm{P}}=\frac{q_{\mathrm{H}} \cdot q_{\mathrm{O}}}{4 \pi \varepsilon \varepsilon_{0}} \cdot \frac{\Delta b}{(b+\Delta b) b},
$$

where $q_{\mathrm{H}}$ and $q_{\mathrm{O}}$ are the charges of atoms $\mathrm{H}$ and $\mathrm{O}$. Positions of the energy minima change under the influence of this piezoelectric potential resulting in overcome of the energy barrier by the proton and in the deprotonation of SB.

Subsequent energy evolution taking place after the deprotonation of SB can proceed in two different ways. One of them could be as follows. After removing the external force and deformation (Fig. 8(c)) the polarization $P$ vanishes. The reason for the proton transfer from $\mathrm{N}$ to $\mathrm{O}$ vanishes together with polarization. The proton becomes energized and creates electromotive force, which could be expressed as the electric flux density $D_{\mathrm{H}+}$. Remaining deformation $\Delta a^{\prime}$ is shown in Fig. 8(c) as a consequence of the inverse piezoelectric effect. The electric flux density creates the electric field $E=D_{\mathrm{H}+} /\left(\varepsilon \varepsilon_{0}\right)$, which causes the deformation of the medium as described by Eq. (15).

On the other hand, the H-bond could be broken if the external strain persists longer than the proton transfer, hence the polarization is swept and the proton is also energized by $D_{\mathrm{H}+}$. During some specific moment $P+D_{\mathrm{H}+}=0$ and the total electric field equals zero. The mechanical elasticity of the bond decreases at this moment as might be concluded from Eq. (13). The deformation increases while the elasticity decreases if the external force is still present, and the bond could be broken (see Fig. 8(c)). The strained medium relaxes and the mechanical energy form disappears while turning into the electrostatic energy of the energized proton. Thus, the force of the active proton pumping is of a mechanical origin.

\section{References}

[1] D. Oesterhelt and W. Stoeckenius, Functions of a new photoreceptor membrane, Proc. Natl. Acad. Sci. USA 70, 2853-2857 (1973).

[2] D. Oesterhelt, Bacteriorhodopsin as an example of a light-driven proton pump, Angew. Chem. Int. Ed. Engl. 15, 17-24 (1976).

[3] R.A. Mathies, S.W. Lin, J.B. Ames, and W.T. Pollard, From femtoseconds to biology: Mechanism of bacteriorhodopsin's light-driven proton pump, Annu. Rev. Biophys. Biophys. Chem. 20, 491-518 (1991).

[4] D. Oesterhelt, J. Tittor, and E. Bamberg, A unifying concept for ion translocation in retinal proteins, J. Bioenerg. Biomembr. 24, 181-191 (1992).

[5] K.J. Rotschild, FTIR difference spectroscopy of bacteriorhodopsin: Toward a molecular model, J. Bioenerg. Biomembr. 24, 147-167 (1992).

[6] J.K. Lanyi, Proton translocation mechanism and energetics in the light-driven pump bacteriorhodopsin, Biochim. Biophys. Acta Bioenerg. 1183, 241-261 (1993).

[7] M.P. Krebs and H.J. Khorana, Mechanism of lightdependent proton translocation by bacteriorhodopsin, J. Bacteriol. 175, 1555-1560 (1993).

[8] K. Schulten, W. Humphrey, I. Logunov, M. Sheves, and D. Xu, Molecular dynamics studies of bacteriorhodopsin's photocycles, Isr. J. Chem. 35, 447-464 (1995).

[9] Y. Kimura, D.G. Vassylyev, A. Miyazawa, A. Kidera, M. Matsushima, K. Mitsuika, K. Murata, T. Hirai, and Y. Fujiyoshi, Surface of bacteriorhodopsin revealed by high-resolution electron crystallography, Nature 389, 206-211 (1997).

[10] L.O. Essen, R. Siegert, W.D. Lehmann, and D. Oesterhelt, Lipid patches in membrane protein oligomers: Crystal structure of the bacteriorhodopsin-lipid complex, Proc. Natl. Acad. Sci. USA 95, 11673-11678 (1998).

[11] H. Luecke, B. Schobert, H.-T. Richter, J.-P. Cartailler, and J.K. Lanyi, Structure of bacteriorhodopsin at $1.55 \AA$ resolution, J. Mol. Biol. 291, 899-911 (1999).

[12] E. Belrhali, P. Nollert, D. Royant, C. Menzel, J.R. Rozenbusch, E.M. Landau, and E. PebayPeyroula, Protein, lipid and water organization in bacteriorhodopsin: A molecular view of the purple membrane at 1.9 angstroms resolution, Structure 7, 909917 (1999). 
[13] B. Schobert, J. Cupp-Vickery, V. Hornak, S.O. Smith, and J.K. Lanyi, Crystallographic structure of the $\mathrm{K}$ intermediate of bacteriorhodopsin: Conservation of free energy after photoisomerization of the retinal, J. Mol. Biol. 321, 715-726 (2002).

[14] J.K. Lanyi and B. Schobert, Mechanizm of proton transport in bacteriorhodopsin from crystallographic structures of the $\mathrm{K}, \mathrm{L}, \mathrm{M}_{1}, \mathrm{M}_{2}$, and $\mathrm{M}_{2}$ ' intermediates of the photocycle, J. Mol. Biol. 328, 439-450 (2003).

[15] J.K. Lanyi, What is real crystallographic structure of the L photointermediate of bacteriorhodopsin?, Biochim. Biophys. Acta 1685, 14-22 (2004).

[16] K. Edman, A. Royant, G. Larsson, F. Jacobson, T. Taylor, D. van der Spoel, E.M. Landau, E. Pebay-Peyroula, and R. Neutze, Deformation of helix $\mathrm{C}$ in the low temperature L-intermediate of bacteriorhodopsin, J. Biol. Chem. 279, 2147-2158 (2004).

[17] J.K. Lanyi and B. Schobert, Crystallographic structure of the retinal and the protein after deprotonation of the schiff base: The switch in the bacteriorhodopsin photocycle, J. Mol. Biol. 321, 727-737 (2002).

[18] L.S. Brown, R. Needleman, and J.K. Lanyi, Conformational change of the E-F interhelical loop in the $M$ photointermediate of bacteriorhodopsin, J. Mol. Biol. 317, 471-478 (2002).

[19] J.K. Lanyi, X-ray diffraction of bacteriorhodopsin photocycle intermediates (Review), Mol. Membr. Biol. 21, 143-150 (2004).

[20] R. Neutze, E. Pebay-Peyroula, K. Edman, A. Royant, J. Navarro, and E.M. Landau, Bacteriorhodopsin: A high-resolution structural view of vectorial proton transport, Biochim. Biophys. Acta 1565, 144-167 (2002).

[21] H. Luecke, B. Schobert, H.-T. Richter, J.-P. Cartailler, and J.K. Lanyi, Structural changes in the M photointermediate of bacteriorhodopsin at 2 angstrom resolution, Science 286, 255-260 (1999).

[22] J.K. Lanyi, Molecular mechanism of ion transport in bacteriorhodopsin: Insights from crystallographic, spectroscopic and mutational studies, J. Phys. Chem. B 104, 11441-11448 (2000).

[23] Bacteriorhodopsin, ed. J.K. Lanyi, Biochim. Biophys. Acta - Bioenergetics 1460, pp. 1-239 (2000).

[24] J.K. Lanyi, Bacteriorhodopsin, Annu. Rev. Physiol. 66, 665-688 (2004).

[25] I. Rousso, E. Khatchatryan, I. Brodsky, R. Nachustai, M. Ottolenghi, M. Sheves, and A. Lewis, Atomic force sensing of light-induced protein dynamics with microsecond time resolution in bacteriorhodopsin and photosynthetic reaction centres, J. Struct. Biol. 119, 158-164 (1997).

[26] G. Varo and J.K. Lanyi, Kinetic and spectroscopic evidence for an irreversible step between deprotonation and reprotonation of the Schiff base in the bacteriorhodopsin photocycle, Biochemistry 30, 5008-5015 (1991).
[27] S. Hayashi and I. Ohmine, Proton transfer in bacteriorhodopsin: Structure, excitation, IR spectra, and potential energy surface analyses by an ab initio QM/MM method, J. Phys. Chem. B 104, 10678-10691 (2000).

[28] S. Hayashi, E. Tajkhorshid, and K. Schulten, Structural changes during the formation of early intermediates in the bacteriorhodopsin photocycle, Biophys. J. 83, 1281-1297 (2002).

[29] S. Hayashi, E. Tajkhorshid, and K. Schulten, Molecular dynamics simulation of bacteriorhodopsin's photoisomerization using ab initio forces for the excited chromophore, Biophys. J. 85, 1440-1449 (2003).

[30] S. Nakajima, K. Ohno, Y. Inoue, and M. Sakurai, Quantum chemical study of the pKa control mechanism for the active center in bacteriorhodopsin and its M intermediate, J. Phys. Chem. B 107, 2867-2874 (2003).

[31] Y.-S. Lee, Dynamics of proton transfer in bacteriorhodopsin, J. Am. Chem. Soc. 126, 2225-2230 (2004).

[32] L.S. Brown, A.K. Dioumaev, R. Needleman, and J.K. Lanyi, Connectivity of the retinal Schiff base to Asp85 and Asp96 during the basteriorhodopsin photocycle: The local-access model, Biophys. J. 75, 14551465 (1998).

[33] H. Kandori, Hydration switch model for the proton transfer in the Schiff base region of bacteriorhodopsin, Biochim. Biophys. Acta 1658, 72-79 (2004).

[34] P. Kietis, M. Vengris, and L. Valkunas, Electrical-tomechanical coupling in purple membranes: Membrane as electrostrictive medium, Biophys. J. 80, 1631-1640 (2001).

[35] H.-W. Trissl and M. Montal, Electrical demonstration of rapid light-induced conformational changes in bacteriorhodopsin, Nature 266, 655-657 (1977).

[36] L.A. Drachev, A.D. Kaulen, and V.P. Skulachev, Time resolution of the intermediate steps in the bacteriorhodopsin-linked electrogenesis, FEBS Lett. 87, 161-167 (1978).

[37] F.T. Hong and M. Montal, Bacteriorhodopsin in model membranes, a component of the displacement photocurrent in the microsecond time scale, Biophys. J. 25, 465-472 (1979).

[38] E.P. Lukashev, E. Vozary, A.A. Kononenko, and A.B. Rubin, Electric field promotion of the bacteriorhodopsin $\mathrm{BR}_{570}$ to $\mathrm{BR}_{412}$ photoconversion in films of Halobacterium halobium purple membranes, Biochim. Biophys. Acta 592, 258-266 (1980).

[39] G. Varo and L. Keszthelyi, Photoelectric signals from dried oriented purple membranes of Halobacterium halobium, Biophys. J. 43, 47-51 (1983).

[40] R. Simmeth and G.W. Rayfield, Evidence that the photoelectric response of bacteriorhodopsin occurs in less than 5 picoseconds, Biophys. J. 57, 1099-1101 (1990).

[41] K.J. Hellingwerf, J.J. Schuurmans, and H.V. Westerhoff, Demonstration of coupling between the protonmotive force across bacteriorhodopsin and the flow 
through its photochemical cycle, FEBS Lett. 92, 181186 (1978).

[42] E. Bamberg, N.A. Dencher, A. Fahr, and M.P. Heyn, Transmembraneous incorporation of photoelectrically active bacteriorhodopsin in planar lipid bilayers, Proc. Natl. Acad. Sci. USA 78, 7502-7506 (1980).

[43] D. Braun, N.A. Dencher, A. Fahr, M. Lindau, and M.P. Heyn, Nonlinear voltage dependence of the lightdriven proton pump current of bacteriorhodopsin, Biophys. J. 53, 617-621 (1988).

[44] R.T. Boconadi, S.G. Taneva, and L. Keszthelyi, Nonproton ion release in purple membrane, Biophys. J. 67, 2490-2492 (1994).

[45] R.T. Boconadi, S.G. Taneva, and L. Keszthelyi, Photoexcitation of the $\mathrm{O}$ intermediate of bacteriorhodopsin and its mutant E204Q, J. Biol. Phys. Chem. 1, 58-63 (2001).

[46] P.B. Kietis, P. Saudargas, and L. Valkunas, Electrostriction of purple membranes and the model of active proton transfer in bacteriorhodopsin, Proc. SPIE 5122, 122-131 (2003).

[47] G. Varo, Dried oriented purple membrane samples, Acta Biol. Acad. Sci. Hung. 32, 301-310 (1981).

[48] G. Varo and L. Keszthelyi, Arrhenius parameters of the bacteriorhodopsin photocycle in dried oriented samples, Biophys. J. 47, 243-246 (1985).

[49] H.W. Trissl, Photoelectric measurements of purple membranes, Photochem. Photobiol. 51, 793-818 (1990).

[50] J.P. Wang, S.K. Yoo, L. Song, and M.A. El-Sayed, Molecular mechanizm of differential photoelectric response of bacteriorhodopsin, J. Phys. Chem. B 101, 3420-3423 (1997).

[51] P. Kietis, D. Linge, P. Saudargas, and L. Valkūnas, Photoelectric response and electrostrictive properties of dried purple membrane films: The comparative study, Lithuanian J. Phys. 41, 477-483 (2001).

[52] R. Jonas, Y. Kontalos, and T.G. Ebrey, Purple membrane: Surface chare density and the multiple effect of $\mathrm{pH}$ cations, Photochem. Photobiol. 52, 1163-1177 (1990).

[53] H.I.A. Mostafa, G. Varo, R. Toth-Boconadi, A. Der, and L. Keszthelyi, Electrooptical measurements on purple membranes containing bacteriorhodopsin mutants, Biophys. J. 70, 468-472 (1996).

[54] S.G. Taneva and I.B. Petkanchin, Surface electric properties of biological systems, Trends in Photochem. Photobiol. 6, 113-139 (1999).

[55] M. Eisenbach and S.R. Caplan, Interaction of purple membrane with solvents II. Mode of interaction, Biochem. Biophys. Acta 554, 281-292 (1979).

[56] G.I. Groma, L. Kelemen, A. Kulcsar, M. Lakatos, and G. Varo, Photocycle of dried acid form of bacteriorhodopsin, Biophys. J. 81, 3432-3441 (2001).

[57] I. Rousso, E. Khatchatryan, Y. Gat, I. Brodsky, M. Ottolenghi, M. Sheves, and A. Lewis, Microsecond atomic force sensing of protein conformational dynamics: implication for the primary light-induced events in bacteriorhodopsin, Proc. Natl. Acad. Sci. USA 94, 7937-7941 (1997).

[58] A. Royant, K. Edman, T. Ursby, E.P. Peyroula, E.M. Landauk, and R. Neutze, Helix deformation is coupled to vectorial proton transport in the photocycle of bacteriorhodopsin, Nature 406, 645-648 (2000).

[59] P. Kietis, M. Vengris, and L. Valkunas, in: Bioelectronic Applications of Photochromic Pigments. NATO Science Series, eds. A. Der and L. Keszthelyi (IOS Press, Amsterdam, 2001) pp. 185-197.

[60] V.I. Pasechnik, Electrostrictive measurements of viscous-elastic properties of lipid bilayer membranes, in: Itogi Nauki i Tekhniki 2, ed. P.G. Kostyuk (VINITI, Moscow, 1982) pp. 267-307 [in Russian].

[61] P.W. Atkins, Physical Chemistry, 6th ed. (Oxford University Press, Oxford, 1998).

[62] P.B. Kietis, Piezoelectric mechanism for the active transport of change in the purple membrane of Halobacterium halobium, Biol. Membranes 1, 13071315 (1984) [in Russian].

[63] P.B. Kietis and R. Rozga, Strained conformation and active transport of ions in bacteriorhodopsin, Biol. Membranes 4, 613-623 (1987)[in Russian].

[64] P.B. Kietis, P. Saudargas, and L. Valkūnas, Timedependent photoconductivity of bacteriorhodopsin, Environmental Chem. Phys. 26, 68-76 (2004).

[65] F. Zhu and K. Schulten, Water and proton conduction through carbon nanotubes as models for biological channels, Biophys. J. 85, 236-244 (2003).

[66] T. Kobayashi, H. Ohtani, J.-I. Iwai, A. Ikegami, and H. Uchiki, Effect of $\mathrm{pH}$ on the photoreaction cycles of bacteriorhodopsin, FEBS Lett. 162, 197-200 (1983).

[67] K. Ludmann, C. Gergely, A. Der, and G. Váró, Electric signals during the bacteriorhodopsin photocycle, determined over a wide $\mathrm{pH}$ range, Biophys. J. 75, 31203126 (1998).

[68] T. Kouyama, T. Nishikawa, T. Tokuhisa, and H. Okumura, Crystal structure of the $\mathrm{L}$ intermediate of bacteriorhodopsin: Evidence for vertical translocation of a water molecule during the proton pumping cycle, J. Mol. Biol. 335, 531-546 (2004).

[69] L.A. Drachev, A.D. Kaulen, L.V. Khitrina, and V.P. Skulachev, Fast stages of photoelectric processes in biological membranes. I. Bacteriorhodopsin, Eur. J. Biochem. 117, 461-470 (1981).

[70] R. Korenstein and B. Hess, Hydration effects on cis-trans isomerization of bacteriorhodopsin, Eur. J. Biochem. 82, 7-11 (1977).

[71] I.K. Starzomska, A. Filarowski, M. Rospenk, A. Koll, and S. Melikova, Proton transfer equilibria in Schiff bases with steric repulsion, J. Phys. Chem. A 108, 2131-2138 (2004).

[72] A. Filarowski, A. Koll, A. Karpfen, and P. Wolschann, Intramolecular hydrogen bond in 
molecular and proton-transfer forms of Schiff

bases, Chem. Phys. 297, 323-332 (2004).

\title{
AKTYVIOJO PROTONŲ TRANSPORTO BAKTERIORODOPSINE PJEZOELEKTRINIS MODELIS
}

\author{
P.B. Kietis ${ }^{\text {a,b }}{ }^{\text {, P. Saudargas }}{ }^{\text {a }}$, L. Valkūnas ${ }^{\text {a,b }}$ \\ ${ }^{\text {a }}$ Fizikos institutas, Vilnius, Lietuva \\ ${ }^{\mathrm{b}}$ Vilniaus universitetas, Vilnius, Lietuva
}

\section{Santrauka}

Transmembraninis baltymas bakteriorodopsinas (BR), konvertuodamas šviesos energiją i kitas energijos formas, vykdo aktyvų protonu transportą per purpurinę membraną (PM) Halobacterium salinarum bakterijose. Čia pristatomi fotoelektriniai sausu PM plèvelių tyrimai. Nanosekundiniu lazerio impulsu sužadintas fotoelektrinis atsakas (PERS) yra priskiriamas protono pernašai BR aktyviajame centre. Pateikiame dvieju potencialiniu duobių modelị, aiškinanti protono pernašą remiantis eksperimentiniais rezultatais. Temperatūriné PERS kinetikos priklausomybẻ leidžia ižvelgti aktyvacini pirmojo protono pernešimo akto pobūdị. Teigiamosios PERS dalies laiko pastovioji gali būti priskirta $\mathrm{L}$ tarpinès būsenos gyvavimo trukmei. Esant mažai $\mathrm{pH}$ vertei, sužadinus šviesa, antroji PERS fazè neatsiranda, o tai rodo, jog rūgščioje aplinkoje protoniniai kanalai yra tiesiog "užkemšami”. Fotoelektrinis atsakas susideda iš dviejų komponenčių, kuriu pirmoji yra sietina su protono pernešimu, o antroji yra poliarizacijos, susijusios su aktyviuoju transportu, pasekmè. Pastaroji komponenté nepriklauso nuo išorinio elektrinio lauko. Pateikiamas fizikinis modelis rodo, kad poliarizacinis laukas yra aktyvu protono pernešimą salygojantis veiksnys (o ne šalutinis efektas). Pradineje stadijoje Šifo bazė ir Asp85 yra zviterjoninèje būsenoje. Šios būsenos energetinè evoliucija nagrinejama aptariant dipolinių medžiagu mechanines-elektrines savybes ir vandeniliniu jungčiu pjezoelektrini efektą. Remiantis pastarụjų metų kristalografinès struktūrinès analizès ir molekulinès dinamikos rezultatais, galima teigti, kad aktyviojo centro poliarizacija yra retinalio izomerizacijos metu atsiradusiu mechaniniu itempimų išdava. Pirmojo protono pernešimo žingsnio pabaigoje visa energija yra sukaupiama energizuotame protone, o poliarizacinis laukas išnyksta. Persiorganizavęs vandenilinių ryšiu tinklas užkerta kelią protono grị̌imui atgal ir protonas, toliau judėdamas per membraną, sukuria transmembranini potencialą. 